\title{
Inhibition by Ricin of Protein Synthesis in vitro
}

\author{
RIBOSOMES AS THE TARGET OF THE TOXIN
}

\author{
By LUCIO MONTANARO, SIMONETTA SPERTI and FIORENZO STIRPE \\ Istituto di Patologia generale dell'Università di Bologna, Via S. Giacomo 14, \\ 40126 Bologna, Italy
}

(Received 21 May 1973)

\begin{abstract}
1. Ricin (a toxic protein from the seeds of Ricinus communis) is a powerful inhibitor of the poly(U)-directed incorporation of phenylalanine into polypeptides catalysed by isolated rat liver ribosomes and elongation factors 1 and 2 (EF 1 and EF 2). The inhibition can be largely overcome by increasing the concentration of ribosomes. 2 . The toxin does not affect the binding of phenylalanyl-tRNA to ribosomes catalysed by EF 1, nor does it inhibit the puromycin reaction used as a test for peptide-bond formation catalysed by ribosomes. 3. Ricin inhibits the ribosome-linked GTP hydrolysis catalysed by EF 2. 4. Ribosomes treated with ricin and washed through sucrose gradients containing $0.6 \mathrm{M}-\mathrm{NH}_{4} \mathrm{Cl}$ are functionally inactive in those assay systems that are sensitive to the presence of added toxin. 5. It is suggested that ricin brings about an irreversible modification of ribosomes which impairs their ability to interact with EF 2 . Since ricin inhibits at a molar concentration much lower than that of ribosomes it probably acts catalytically. No added cofactor is necessary for the inhibitory action of the toxin.
\end{abstract}

Ricin, a protein from castor beans (the seeds of Ricinus communis), is extremely toxic to animals and causes necrotic lesions in the gastrointestinal system, in the spleen and lymph nodes, and in the liver (Waller et al., 1966).

It has been reported that ricin has an inhibitory effect on the growth of Ehrlich ascites tumour (Lin et al., 1970) and brings about inhibition of protein synthesis in Ehrlich-ascites-tumour cells in vitro and in rat liver in vivo, affecting DNA synthesis only slightly and RNA synthesis not at all (Lin et al., 1971). Olsnes \& Pihl $(1972 a)$ reported that ricin inhibits protein synthesis in a cell-free system prepared from rabbit reticulocytes, and suggested that this effect was due to inhibition of the elongation of polypeptide chains, the initiation being unaffected.

The present experiments were undertaken with the aim of clarifying the mechanism whereby ricin affects protein synthesis. With the use of a reconstituted system of rat liver ribosomes and EF $1 *$ and EF 2 evidence was obtained (i) that ricin inhibits the elongation of polypeptide chains by interfering with the translocation reaction catalysed by EF 2, without affecting the binding of aminoacyl-tRNA, and (ii)

* Abbreviations: EF 1, elongation factor 1; EF 2, elongation factor 2; A site, aminoacyl-tRNA site; $P$ site, peptidyl-tRNA site; GTPase, guanosine triphosphatase. that this is due to damage to the ribosomes, EF 2 appearing unaffected.

\section{Experimental}

\section{Materials}

Ricin was purified as described by Moulé (1951). Its $\mathrm{LD}_{50}$, tested in Wistar albino rats, was $7.5 \mu \mathrm{g} / \mathrm{kg}$ body wt. given intraperitoneally. Its molecular weight was assumed to be 65000 (Lin et al., 1970). Diphtheria toxin, purified by the method of Pope \& Stevens (1958), was obtained from the Istituto Sieroterapico e Vaccinogeno Toscano 'Sclavo' (Siena, Italy).

All the chemicals used were analytical grade. Norit A (activated charcoal), NAD ${ }^{+}$and GTP were products of Sigma Chemical Co., St. Louis, Mo., U.S.A. Puromycin dihydrochloride was from Nutritional Biochemicals Corp., Cleveland, Ohio, U.S.A. Poly(U) (potassium salt) was from C. F. Boehringer und Soehne G.m.b.H., Mannheim, Germany. [ $\left.\gamma_{-}{ }^{32} \mathrm{P}\right]-$ GTP $(509 \mathrm{mCi} / \mathrm{mmol}),\left[8-{ }^{3} \mathrm{H}\right] \mathrm{GTP}(12 \mathrm{Ci} / \mathrm{mmol})$ and $\left[8-{ }^{3} \mathrm{H}\right.$ ]puromycin $(2 \mathrm{Ci} / \mathrm{mmol})$ were from The Radiochemical Centre, Amersham, Bucks., U.K. [adenosine $\left.{ }^{3} \mathrm{H}\right] \mathrm{NAD}^{+}(1.13 \mathrm{Ci} / \mathrm{mmol})$ and $\mathrm{L}-\left[{ }^{14} \mathrm{C}\right]$ phenylalanyl-tRNA $\left(0.137 \mu \mathrm{Ci}\right.$ of $\left[{ }^{14} \mathrm{C}\right]$ phenylalanine/mg of tRNA; $385 \mathrm{mCi} / \mathrm{mmol}$ of L-phenylalanine) were 
obtained from New England Nuclear Corp., Boston, Mass., U.S.A.

\section{Preparation of ribosomes}

Rat liver polyribosomes were prepared as described by Staehelin \& Falvey (1971) and stored at $-20^{\circ} \mathrm{C}$ in small portions containing $150-300 E_{260}$ units $/ \mathrm{ml}$.

Puromycin-treated ribosomes. Ribosomes freed of endogenous peptidyl-tRNA were prepared by incubating polyribosomes at a final concentration of $20 E_{260}$ units $/ \mathrm{ml}$ in a complete protein-synthesizing system (Staehelin \& Falvey, 1971) containing $50 \mu \mathrm{g}$ of puromycin $/ \mathrm{ml}$. After $50 \mathrm{~min}$ at $35^{\circ} \mathrm{C}$, the mixture was chilled in ice; $\mathrm{KCl}$ and $\mathrm{NH}_{4} \mathrm{Cl}$ were added to final concentrations of $0.25 \mathrm{M}$ and $0.5 \mathrm{M}$ respectively and $9 \mathrm{ml}$ samples were layered over discontinuous sucrose gradients consisting of $9 \mathrm{ml}$ of $2 \mathrm{M}$-sucrose and $9 \mathrm{ml}$ of $0.7 \mathrm{M}$-sucrose, both containing $20 \mathrm{~mm}$-Tris$\mathrm{HCl}$ buffer, pH7.5, $3 \mathrm{~mm}$-magnesium acetate and $1 \mathrm{mM}$-dithiothreitol; $0.6 \mathrm{M}-\mathrm{NH}_{4} \mathrm{Cl}$ was present in the $0.7 \mathrm{M}$-sucrose layer. The gradients were centrifuged for $24 \mathrm{~h}$ at $4^{\circ} \mathrm{C}$ in a Spinco 30 Angle rotor (Beckman model L2-65K ultracentrifuge) at $78000 \mathrm{~g}_{\mathrm{av}}$. Two further washings on the same discontinuous sucrose gradients were performed to remove all adherent EF 2 and GTP from ribosomes.

Translocated ribosomes. Ribosomes with their nascent peptidyl-tRNA at the P site were prepared as described by Baliga \& Munro (1972) by incubating polyribosomes at a final concentration of $3 E_{260}$ units $/ \mathrm{ml} \mathrm{in} 54 \mathrm{ml}$ of a reaction medium containing $0.5 \mathrm{nM}-\mathrm{GTP}$ and $24 \mu \mathrm{g}$ of EF 2 protein $/ \mathrm{ml}$ measured by the method of Lowry et al. (1951) with bovine serum albumin as standard. The ionic conditions were $150 \mathrm{~mm}-\mathrm{NH}_{4} \mathrm{Cl}, 7.5 \mathrm{~mm}$-magnesium acetate, $20 \mathrm{~mm}$-Tris- $\mathrm{HCl}$ buffer, pH 7.5, $1 \mathrm{~mm}$-dithiothreitol. After $10 \mathrm{~min}$ at $37^{\circ} \mathrm{C}$, the ribosomes were spun down and then washed twice on discontinuous sucrose gradients containing $0.6 \mathrm{M}-\mathrm{NH}_{4} \mathrm{Cl}$, as for puromycintreated ribosomes.

Non-translocated ribosomes. Control ribosomes were incubated under the same ionic conditions as translocated ribosomes, but in the absence of EF 2 and GTP. They were then washed through the same sucrose gradients.

Ricin-treated ribosomes. The incubation mixtures for the preparation of translocated and non-translocated ribosomes contained ricin at a final concentration of $2 \mu \mathrm{g} / \mathrm{ml}$. After $10 \mathrm{~min}$ at $37^{\circ} \mathrm{C}$, ribosomes were spun down and washed twice through the discontinuous sucrose gradients containing $\mathrm{NH}_{4} \mathrm{Cl}$.

All ribosomal pellets were resuspended in $0.25 \mathrm{M}$ sucrose and ribosome concentration was calculated from the $E_{260}$, assuming $E_{1 \mathrm{~cm}}^{1 \%}$ to be 145 and the molecular weight of the ribosome to be $4.1 \times 10^{6}$ (Baliga \& Munro, 1972). With the latter value, $1 \mathrm{mg}$ of ribosomes corresponds approximately to $250 \mathrm{pmol}$.

\section{Other methods}

Preparation of elongation factors. EF 1 and EF 2 were obtained from rat liver 'pH 5 supernatant' as described by Moldave et al. (1971). After adsorption on hydroxyapatite and stepwise elution with $0.125 \mathrm{M}$-, $0.175 \mathrm{M}$ - and $0.250 \mathrm{M}$-potassium phosphate buffer, pH6.8, the EF 2 present in the 0.125 M-phosphate eluate and the EF 1 present in the $0.250 \mathrm{M}$-phosphate eluate were further purified by separate chromatography on DEAE-cellulose as described by Felicetti \& Lipmann (1968). The protein content of the enzyme preparations was determined by the method of Lowry et al. (1951) with bovine serum albumin as standard.

Poly $(U)$-directed incorporation of phenylalanine into polypeptide. The reaction medium used contained in a final volume of $0.25 \mathrm{ml}: 150 \mathrm{~mm}-\mathrm{NH}_{4} \mathrm{Cl}, 9 \mathrm{~mm}-$ magnesium acetate, $20 \mathrm{~mm}$-Tris- $\mathrm{HCl}$ buffer, $\mathrm{pH} 7.5$, $1 \mathrm{~mm}$-dithiothreitol, $2 \mathrm{mM}$-GTP, $73 \mu \mathrm{g}$ of $\left[{ }^{14} \mathrm{C}\right]$ phenylalanyl-tRNA and $200 \mu \mathrm{g}$ of poly(U). Ribosomes and the EF 1 and EF 2 preparations were present in the amounts indicated in the legends to Tables. After $10 \mathrm{~min}$ at $37^{\circ} \mathrm{C}, 0.25 \mathrm{ml}$ of $10 \%(\mathrm{w} / \mathrm{v})$ trichloroacetic acid was added and the samples were heated at $90^{\circ} \mathrm{C}$ for $10 \mathrm{~min}$. The hot-acid-insoluble radioactivity was collected on glass-fibre filters (Whatman GF/C), washed with $5 \%$ trichloroacetic acid and measured.

Phenylalanyl-tRNA binding to ribosomes. Ribosomes $(500 \mu \mathrm{g}), 146 \mu \mathrm{g}$ of $\left[{ }^{14} \mathrm{C}\right]$ phenylalanyl-tRNA and $200 \mu \mathrm{g}$ of poly(U) were incubated at $37^{\circ} \mathrm{C}$ for $10 \mathrm{~min}$ in $0.5 \mathrm{ml}$ of $20 \mathrm{~mm}$-Tris $-\mathrm{HCl}$ buffer, $\mathrm{pH} 7.5$, containing $150 \mathrm{~mm}-\mathrm{NH}_{4} \mathrm{Cl}, 9 \mathrm{~mm}$-magnesium acetate, $1 \mathrm{~mm}$-dithiothreitol and $2 \mathrm{~mm}$-GTP. Most of the samples also contained $0.5 \mathrm{~mm}$-puromycin (Ibuki \& Moldave, 1968). Incubations were carried out in the presence and in the absence of $30 \mu \mathrm{g}$ of EF 1 protein. At the end of incubation, the reaction mixtures were diluted with $5 \mathrm{ml}$ of ice-cold $20 \mathrm{~mm}$-Tris- $\mathrm{HCl}$ buffer, pH 7.5, containing $150 \mathrm{~mm}-\mathrm{NH}_{4} \mathrm{Cl}, 9 \mathrm{~mm}$-magnesium acetate and $1 \mathrm{~mm}$-dithiothreitol and filtered immediately on Millipore filters (HA; average pore size $0.45 \mu \mathrm{m}$ ). The filters were washed three times with $5 \mathrm{ml}$ of cold buffer, dried and assayed for radioactivity.

Peptidyl $\left[{ }^{3} \mathrm{H}\right]$ puromycin reaction. Ribosomes $(250 \mu \mathrm{g})$ were allowed to react with puromycin dihydrochloride in a mixture containing, in $0.5 \mathrm{ml}$, $60 \mathrm{~mm}$-Tris- $\mathrm{HCl}$ buffer, pH7.5, $12 \mathrm{~mm}-\mathrm{MgCl}_{2}$, $300 \mathrm{mM}-\mathrm{NH}_{4} \mathrm{Cl}$ and $10 \mu \mathrm{M}-\left[{ }^{3} \mathrm{H}\right]$ puromycin. After $15 \mathrm{~min}$ of incubation at $37^{\circ} \mathrm{C}$ the samples were analysed for hot-acid-insoluble radioactivity (Skogerson \& Moldave, 1968).

GTPase assay. GTPase activity was assayed as described by Felicetti \& Lipmann (1968) in incubation mixtures containing, in $0.125 \mathrm{ml}, 50 \mathrm{~mm}$-Tris$\mathrm{HCl}$ buffer, pH7.5, $80 \mathrm{~mm}-\mathrm{NH}_{4} \mathrm{Cl}, 10 \mathrm{~mm}-\mathrm{MgCl}_{2}$, $16 \mathrm{~mm}$-dithiothreitol and $5 \mathrm{nmol}$ of $\left[\gamma-{ }^{32} \mathrm{P}\right] \mathrm{GTP}$ (diluted with unlabelled GTP to a specific radioactivity of 50 d.p.m./pmol); $200 \mu \mathrm{g}$ of $\mathrm{NH}_{4} \mathrm{Cl}$-washed 
ribosomes and $24 \mu \mathrm{g}$ of EF 2 protein were present where indicated. After $15 \mathrm{~min}$ at $37^{\circ} \mathrm{C}$, the reaction was terminated by the addition of $1 \mathrm{ml}$ of ice-cold $2.6 \%(\mathrm{w} / \mathrm{v})$ trichloroacetic acid containing $1 \mathrm{mM}-$ $\mathrm{KH}_{2} \mathrm{PO}_{4}$ and $30 \mathrm{mg}$ of Norit A. The mixture was shaken for 30 s on a Vortex mixer and centrifuged for $5 \mathrm{~min}$ at $2500 \mathrm{~g}$ in a Martin Christ Universal centrifuge at $2^{\circ} \mathrm{C}$. Supernatants were filtered through Whatman no. 1 paper and $0.1 \mathrm{ml}$ samples of the filtrates were assayed for radioactivity. Ribosome-linked GTPase activity was calculated by subtracting the activities of ribosomes alone and of EF 2 alone from the total activity observed when the two components were incubated together.

Binding of $\left[{ }^{3} H\right] G T P$ to $E F 2$. The effect of ricin on the binding of GTP to EF 2 was studied by equilibrium-dialysis experiments performed as described by Sperti et al. (1971). One set of chambers contained EF $2(624 \mu \mathrm{g}$ of protein $/ \mathrm{ml})$ in one compartment and $\left[{ }^{3} \mathrm{H}\right] \mathrm{GTP}$ at the same initial concentration $(1-18 \mathrm{nM})$ in both compartments. The second set contained, besides EF 2 and GTP, ricin $(20 \mu \mathrm{g} / \mathrm{ml})$ in both compartments. After $24 \mathrm{~h}$ dialysis at $5^{\circ} \mathrm{C}, 0.1 \mathrm{ml}$ samples were withdrawn from both compartments and assayed for radioactivity. The plot of the reciprocal of bound (b) against the reciprocal of free $(c)\left[{ }^{3} \mathrm{H}\right]$ GTP concentration according to the equation (Sperti et al., 1971):

$$
1 / b=1 / n p+K_{\mathrm{d}} / n p c
$$

gave a straight line, from which the concentration of the enzyme-binding sites ( $n p$, where $n$ is the stoicheiometry and $p$ the molar concentration of the interacting protein) and the dissociation constant $\left(K_{\mathrm{d}}\right)$ of the complex of EF 2 with GTP could be calculated.

$\left[{ }^{3} \mathrm{H}\right] \mathrm{ADP}$-ribosylation. ADP-ribosylation of EF 2 was performed by allowing the EF 2 preparation to react with [adenosine ${ }^{3} \mathrm{H} \mathrm{NAD}^{+}$and diphtheria toxin as described by Raeburn et al. (1971). The concentration of EF 2 in the enzyme preparations was calculated from the specific radioactivity of the $\left[{ }^{3} \mathrm{H}\right] \mathrm{NAD}^{+}$ employed.

Radioactivity measurements. Dried filters or aqueous samples were put in scintillation vials containing $6 \mathrm{ml}$ of ethylene glycol monomethyl ether and $10 \mathrm{ml}$ of scintillation fluid [0.05\% 1,4-bis-(5-phenyloxazol-2-yl)benzene and $0.4 \%, 2,5$-diphenyloxazole in toluene] and were counted for radioactivity in a Nuclear-Chicago mark I scintillation counter (counting efficiency approx. $60 \%$ for ${ }^{14} \mathrm{C}, 15 \%$ for ${ }^{3} \mathrm{H}$ and $40 \%$ for ${ }^{32} \mathrm{P}$ ). The counts were corrected to $100 \%$ efficiency.

\section{Results}

Poly(U)-directed phenylalanine incorporation into polypeptide was severely inhibited in the presence of ricin. In the complete system containing the two elongation factors and $30 \mathrm{pmol}$ of non-translocated ribo- somes, the degree of inhibition was $33 \%$ in the presence of $0.2 \mu \mathrm{g}$ of $\mathrm{ricin} / \mathrm{ml}, 73 \%$ in the presence of $2 \mu \mathrm{g}$ of ricin $/ \mathrm{ml}$ and $80 \%$ in the presence of $20 \mu \mathrm{g}$ of ricin $/ \mathrm{ml}$. Similarly, with puromycin-treated ribosomes inhibition was $35 \%$ in the presence of $0.2 \mu \mathrm{g}$ of ricin $/ \mathrm{ml}, 72 \%$ in the presence of $2 \mu \mathrm{g}$ of $\mathrm{ricin} / \mathrm{ml}$ and $82 \%$ in the presence of $20 \mu \mathrm{g}$ of ricin $/ \mathrm{ml}$. These inhibitions are calculated from the data reported in Fig. 1. The lower curve in Fig. 1 shows, at the same concentrations of ricin, the incorporation of $\left[{ }^{14} \mathrm{C}\right]$ phenylalanine on addition of EF 1 alone to ribosomes washed through sucrose gradients lacking $\mathrm{NH}_{4} \mathrm{Cl}$. The incorporation of $\left[{ }^{14} \mathrm{C}\right]$ phenylalanine depended on endogenous EF 2 adherent to ribosomes. In these conditions the inhibition of phenylalanine incorporation was less severe at the lower concentrations of toxin, as if more ricin were needed to interfere with the ribosome activity catalysed by endogenous EF 2 .

To identify in the complete system the component(s) sensitive to the toxin the inhibition of phenylalanine polymerization induced by ricin was measured in experiments in which the concentrations of ribosomes and of the enzymes were varied independently. Table 1 shows the inhibition brought about

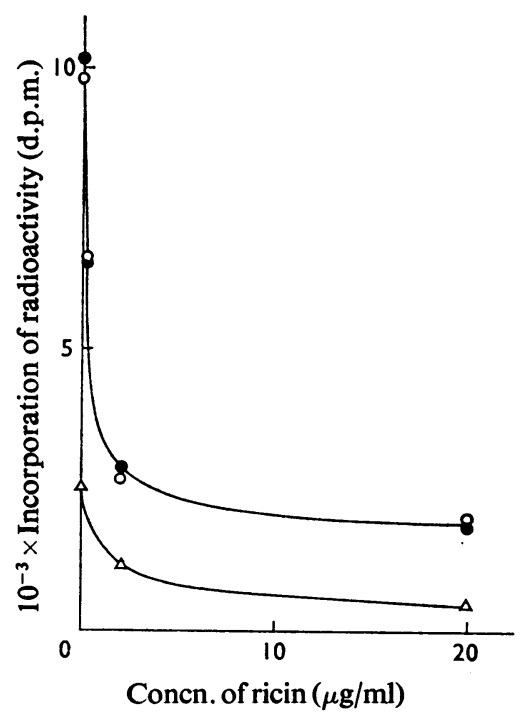

Fig. 1. Effect of ricin on poly $(U)$-directed phenylalanine incorporation into polypeptide

The otherwise standard incubation mixture contained (in $0.25 \mathrm{ml}$ ): upper curve, $15 \mu \mathrm{g}$ of EF 1 protein, $50 \mu \mathrm{g}$ of EF 2 protein and $30 \mathrm{pmol}$ of $\mathrm{NH}_{4} \mathrm{Cl}$-washed non-translocated $(0)$ or puromycin-treated ribosomes $(\bullet)$; lower curve, $15 \mu \mathrm{g}$ of EF 1 protein and $30 \mathrm{pmol}$ of ribosomes washed through sucrose gradients without $\mathrm{NH}_{4} \mathrm{Cl}(\triangle)$. 
by ricin $(0.8 \mu \mathrm{g} / \mathrm{ml})$ in the presence of a constant concentration of EF 1 and at two different concentrations of EF 2 and of non-translocated ribosomes. The extent of the inhibition was practically the same at two concentrations of EF 2 differing by a factor of 5 . On the other hand, the inhibition, which was almost complete at the lower concentration of ribosomes, was decreased to less than $30 \%$ by a 2.5 -fold increase in ribosome concentration. Since inhibition could be overcome by increasing the concentration of ribosomes, these appeared to be the main target of the toxin in the phenylalanine-incorporating system.

A direct effect of ricin on ribosomes was clearly indicated in experiments in which ribosomes were preincubated with the toxin, washed, and then tested for phenylalanine incorporation without further addition of ricin. Table 2 shows the activity of translocated and non-translocated ribosomes isolated as described in the Experimental section from preincubation mixtures in the absence or in the presence of ricin $(2 \mu \mathrm{g} / \mathrm{ml})$. The addition of EF 1 to once-washed non-translocated ribosomes (EF 2 absent from the preincubation mixture) induced a slight incorporation of $\left[{ }^{14} \mathrm{C}\right]$ phenylalanine, which increased 10 fold on addition of EF 2. When ricin was present during preincubation, the incorporation in the presence of EF 1 alone was decreased only slightly, whereas the increment due to EF 2 was completely abolished. A second washing of the ribosomes did not modify the results. With translocated ribosomes (EF 2 and GTP present during preincubation) one $\mathrm{NH}_{4} \mathrm{Cl}$ washing was insufficient to remove the EF 2

Table 1. Effectiveness of ricin as inhibitor of phenylalanine polymerization catalysed by low and high concentrations of ribosomes and $E F 2$

The otherwise standard assay mixture (see the Experimental section) contained (in $0.25 \mathrm{ml}$ ): $90 \mu \mathrm{g}$ of EF 1 protein and two different concentrations of ribosomes and EF 2 as indicated.

\begin{tabular}{|c|c|c|c|c|}
\hline \multirow[b]{2}{*}{ Content of ribosomes } & \multirow[b]{2}{*}{$\begin{array}{l}\text { Content of } \\
\text { EF } 2 \text { protein }\end{array}$} & \multicolumn{2}{|c|}{ Radioactivity incorporated (d.p.m.) } & \multirow[b]{2}{*}{$\begin{array}{c}\text { Inhibition } \\
(\%)\end{array}$} \\
\hline & & $\begin{array}{c}\text { Ricin absent } \\
\text { from assay mixture }\end{array}$ & $\begin{array}{c}\text { Ricin present } \\
(0.8 \mu \mathrm{g} / \mathrm{ml}) \\
\text { in assay mixture }\end{array}$ & \\
\hline Low $(110 \mu \mathrm{g} ; 27.5 \mathrm{pmol})$ & $\begin{array}{l}\text { Low }(24 \mu \mathrm{g}) \\
\text { High }(120 \mu \mathrm{g})\end{array}$ & $\begin{array}{r}960 \\
6694\end{array}$ & $\begin{array}{r}94 \\
1329\end{array}$ & $\begin{array}{l}90 \\
80\end{array}$ \\
\hline High $(275 \mu \mathrm{g} ; 68.75 \mathrm{pmol})$ & $\begin{array}{l}\text { Low }(24 \mu \mathrm{g}) \\
\text { High }(120 \mu \mathrm{g})\end{array}$ & $\begin{array}{l}3071 \\
9302\end{array}$ & $\begin{array}{l}2254 \\
7293\end{array}$ & $\begin{array}{l}27 \\
22\end{array}$ \\
\hline
\end{tabular}

Table 2. Effect of preincubation of ribosomes with ricin on $\left[{ }^{14} \mathrm{C}\right]$ phenylalanine incorporation catalysed by EF 1 and EF 2

Ribosomes sedimented from the various preincubation mixtures were washed twice with $0.6 \mathrm{M}-\mathrm{NH}_{4} \mathrm{Cl}$ as described in the Experimental section (see under 'Preparation of ribosomes'). Then $200 \mu \mathrm{g}(50 \mathrm{pmol})$ of the once-washed ribosomes and $200 \mu \mathrm{g}(50 \mathrm{pmol})$ of the twice-washed ribosomes were tested under the reaction conditions described in the Experimental section (see under 'Poly(U)-directed incorporation of phenylalanine into polypeptide'). Where indicated, $45 \mu \mathrm{g}$ of EF 1 and $48 \mu \mathrm{g}$ of EF 2 protein were added.

\begin{tabular}{|c|c|c|c|c|c|}
\hline \multirow[b]{2}{*}{ Ribosome preparation } & \multirow[b]{2}{*}{$\begin{array}{l}\text { Preincubation } \\
\text { additions }\end{array}$} & \multirow{2}{*}{$\begin{array}{c}\text { Number of } \\
0.6 \mathrm{M}-\mathrm{NH}_{4} \mathrm{Cl} \\
\text { washings }\end{array}$} & \multicolumn{3}{|c|}{ Radioactivity incorporated (d.p.m.) } \\
\hline & & & $\begin{array}{l}\text { No enzyme } \\
\text { added }\end{array}$ & $\begin{array}{c}\text { EF 1 } \\
\text { added }\end{array}$ & $\begin{array}{c}\mathrm{EF} 1+\mathrm{EF} 2 \\
\text { added }\end{array}$ \\
\hline \multirow[t]{3}{*}{ Non-translocated ribosomes } & None & $\begin{array}{l}\text { One } \\
\text { Two }\end{array}$ & $\begin{array}{l}83 \\
89\end{array}$ & $\begin{array}{l}968 \\
977\end{array}$ & $\begin{array}{l}9131 \\
9751\end{array}$ \\
\hline & Ricin & One & 87 & 611 & 586 \\
\hline & & Two & 85 & 522 & 560 \\
\hline \multirow[t]{4}{*}{ Translocated ribosomes } & EF 2, GTP & One & 93 & 3499 & 9772 \\
\hline & & Two & 76 & 993 & 8870 \\
\hline & EF 2, GTP, ricin & One & 81 & 1274 & 1023 \\
\hline & & Two & 89 & 1155 & 989 \\
\hline
\end{tabular}


that had adhered to ribosomes during preincubation. In fact the addition of EF 1 alone caused a significant incorporation of $\left[{ }^{14} \mathrm{C}\right]$ phenylalanine, which increased threefold on addition of EF 2 . When ricin was present the binding of EF 2 to ribosomes during preincubation appeared decreased, and, as with nontranslocated ribosomes, further addition of EF 2 was completely ineffective on $\left[{ }^{14} \mathrm{C}\right]$ phenylalanine incorporation. After the second $\mathrm{NH}_{4} \mathrm{Cl}$ washing the incorporations with translocated ribosomes approached those observed with non-translocated ribosomes. Free ricin from the preincubation mixtures did not co-sediment with ribosomes through the $\mathrm{NH}_{4} \mathrm{Cl}$ washing procedure, since the addition of ricin-treated ribosomes to control ribosomes did not affect their phenylalanine-polymerizing activity.

Table 3 shows the effect of ricin on the binding of $\left[{ }^{14} \mathrm{C}\right]$ phenylalanyl-tRNA to ribosomes catalysed by EF 1. The data were obtained after subtraction of two blanks, the total radioactivity bound to ribosomes in the absence of EF 1 and the hot-acid-insoluble radioactivity recovered from duplicate samples incu- bated in the presence of EF 1. The latter value, which indicates the extent of $\left[{ }^{14} \mathrm{C}\right]$ phenylalanine polymerization in the presence of EF 1, was negligible when puromycin-treated ribosomes were used or when $0.5 \mathrm{~mm}$ puromycin was present during the binding assay (Ibuki \& Moldave, 1968). The data reported in Table 3 clearly indicate that the presence of ricin in the incubation medium did not affect the binding of phenylalanyl-tRNA to puromycin-treated ribosomes (Expt. $1)$; similarly, the binding activity of ribosomes isolated from preincubation mixtures containing ricin was scarcely affected as compared with that of ribosomes preincubated in the absence of ricin (Expt. 2).

Table 4 shows the effect of ricin on the peptidyl$\left[{ }^{3} \mathrm{H}\right]$ puromycin reaction catalysed by translocated and non-translocated ribosomes. In the absence of ricin the difference in the amount of $\left[{ }^{3} \mathrm{H}\right]$ puromycin incorporated by translocated and non-translocated ribosomes indicates that $40 \%$ of the total peptidyltRNA had translocated from the A site to the P site of ribosomes during preincubation with EF 2 and GTP. The presence of ricin during preincubation did

Table 3. Effect of ricin on the EF 1-catalysed binding of $\left[{ }^{14} \mathrm{C}\right]$ phenylalanyl-tRNA to ribosomes

In Expt. 1, $500 \mu \mathrm{g}(125 \mathrm{pmol})$ of puromycin-treated ribosomes (see the Experimental section) was tested for $\left[{ }^{14} \mathrm{C}\right]$ phenylalanyl-tRNA binding in the absence and in the presence of different concentrations of ricin added to $0.5 \mathrm{ml}$ of the incubation medium described in the Experimental section. In Expt. 2, $500 \mu \mathrm{g}(125 \mathrm{pmol})$ of $\mathrm{NH}_{4} \mathrm{Cl}-$ washed ribosomes isolated from preincubation mixtures carried out in the absence (control) or in the presence (ricin-treated) of ricin $(2 \mu \mathrm{g} / \mathrm{ml})$ was tested for $\left[{ }^{14} \mathrm{C}\right]$ phenylalanyl-tRNA binding as described in the Experimental section; $0.5 \mathrm{~mm}$-puromycin was present in the incubation medium. The radioactivity bound in the absence of EF 1, determined as a routine, was less than $30 \%$ of the total bound radioactivity; the EF 1-catalysed binding was calculated by difference.

$\begin{array}{cccc}\text { Expt. } & \text { Ribosomes } & \text { Additions to incubation medium } & \text { Radioactivity bound (d.p.m.) } \\ 1 & \text { Puromycin-treated } & \text { None } & 1062 \\ & & \text { Ricin }(0.2 \mu \mathrm{g} / \mathrm{ml}) & 1082 \\ & & \text { Ricin }(2.0 \mu \mathrm{g} / \mathrm{ml}) & 1040 \\ & & \text { Ricin }(20.0 \mu \mathrm{g} / \mathrm{ml}) & 931 \\ 2 & \text { Control } & \text { Puromycin } & 976 \\ & \text { Ricin-treated } & \text { Puromycin } & 892\end{array}$

Table 4. Effect of ricin on the peptidyl $-\left[{ }^{3} \mathrm{H}\right]$ puromycin reaction

Ribosomes $(250 \mu \mathrm{g}, 62.5 \mathrm{pmol})$ isolated from the various preincubation mixtures were tested in $0.5 \mathrm{ml}$ of the peptidyl- $\left[{ }^{3} \mathrm{H}\right]$ puromycin assay mixture described in the Experimental section.

$\left[{ }^{3} \mathrm{H}\right]$ Puromycin reacted ( $\mathrm{pmol} / \mathrm{pmol}$ of ribosomes)

Ribosome preparation

Non-translocated ribosomes

Translocated ribosomes

\section{Preincubation} additions

None

Ricin

EF 2, GTP

EF 2, GTP, ricin

$\begin{array}{cc}\begin{array}{c}\text { Ricin absent from } \\ \text { assay mixture }\end{array} & \begin{array}{c}\text { Ricin present }(20 \mu \mathrm{g} / \mathrm{ml}) \\ \text { in assay mixture }\end{array}\end{array}$

0.12

0.13

0.13

0.17

0.20

0.21

0.20

0.25

Vol. 136 
Table 5. Effect of ricin on the ribosome-linked GTPase activity of EF 2

$\mathrm{NH}_{4} \mathrm{Cl}$-washed ribosomes $(200 \mu \mathrm{g}, 125 \mathrm{pmol})$ from preincubations in the absence (control) or in the presence (ricin-treated) of ricin $(2 \mu \mathrm{g} / \mathrm{ml})$ were tested in $0.125 \mathrm{ml}$ of the GTPase assay system as described in the Experimental section.

\begin{tabular}{|c|c|c|c|c|c|}
\hline & \multicolumn{2}{|c|}{ Incubation system } & \multirow{2}{*}{$\begin{array}{c}{\left[\gamma^{-32} \mathrm{P}\right] \mathrm{GTP}} \\
\text { hydrolysed } \\
(\mathrm{pmol})\end{array}$} & \multicolumn{2}{|c|}{$\begin{array}{c}\text { Ribosome-linked GTPase } \\
\text { activity of EF } 2\end{array}$} \\
\hline & $\begin{array}{l}\text { Complementary } \\
\text { factors }\end{array}$ & $\underset{(20 \mu \mathrm{g} / \mathrm{ml})}{\operatorname{Ricin}}$ & & $\begin{array}{c}\text { (pmol of }\left[\gamma^{-32} \mathrm{P}\right] \mathrm{GTP} \\
\text { hydrolysed) }\end{array}$ & $\begin{array}{l}\text { Activity } \\
(\%)\end{array}$ \\
\hline \multirow[t]{3}{*}{ Control ribosomes } & Ribosomes & - & 208 & & \\
\hline & EF 2 & - & 240 & & \\
\hline & Ribosomes + EF 2 & - & 1258 & 810 & 100 \\
\hline \multirow[t]{3}{*}{ Control ribosomes } & Ribosomes & + & 195 & & \\
\hline & EF 2 & + & 218 & & \\
\hline & Ribosomes + EF 2 & + & 762 & 349 & 43 \\
\hline \multirow{3}{*}{ Ricin-treated ribosomes } & Ribosomes & - & 208 & & \\
\hline & EF 2 & - & 230 & & \\
\hline & Ribosomes + EF 2 & - & 780 & 342 & 42 \\
\hline \multirow[t]{3}{*}{ Ricin-treated ribosomes } & Ribosomes & + & 210 & & \\
\hline & EF 2 & + & 200 & & \\
\hline & Ribosomes + EF 2 & + & 720 & 310 & 38 \\
\hline
\end{tabular}

not affect this single translocation. A value of $20 \%$ for ribosomes reactive with puromycin after translocation is a common finding reported by several authors (Alberghina et al., 1971; Baliga \& Munro, 1972; Schneider \& Maxwell, 1973). The data of Table 4 show also that the presence of ricin in the peptidyl$\left[{ }^{3} \mathrm{H}\right]$ puromycin reaction mixture did not decrease the amount of puromycin-peptide formed. If the puromycin reaction is to be considered an assay for normal peptide formation, we must conclude that transpeptidation is not affected by ricin.

Since ricin did not affect the ability of ribosomes either to bind phenylalanyl-tRNA or to catalyse the peptidyl-puromycin reaction, attention was focused on the interaction between ribosomes and EF 2 . Table 5 shows the effect of ricin on the ribosomelinked GTPase activity of EF 2, obtained by subtracting the activities of ribosomes alone and of EF 2 alone from the activity observed when the two components were incubated together. Ricin did not modify the amount of GTP hydrolysed either by ribosomes or by EF 2 tested separately, but considerably decreased the increment observed when the two components were incubated together. The residual activity was $43 \%$ when ricin $(20 \mu \mathrm{g} / \mathrm{ml})$ was present in the assay system, and $42 \%$ when ribosomes isolated from preincubation mixtures containing $2 \mu \mathrm{g}$ of $\mathrm{ricin} / \mathrm{ml}$ were tested. The further addition of ricin to ricin-treated ribosomes hardly modified this value.

The fact that ricin did not modify the amount of GTP hydrolysed by EF 2 alone is consistent with the results of equilibrium-dialysis experiments performed to study the effect of ricin $(20 \mu \mathrm{g} / \mathrm{ml})$ on the binding of $\left[{ }^{3} \mathrm{H}\right]$ GTP to EF 2. Although ricin was added in a fivefold molar excess with respect to EF 2 (as indicated by the value for the molarity of binding sites of EF 2 calculated from the ADP-ribosylation test), no modification of the dissociation constant of the EF 2GTP complex $\left(K_{\mathrm{d}}=1 \times 10^{-7} \mathrm{M}\right)$ nor of the molarity of the binding sites of the enzyme for GTP $\left(n p=7 \times 10^{-8} \mathrm{M}\right)$ was observed.

\section{Discussion}

Ricin is a very powerful inhibitor of the poly(U)directed phenylalanine incorporation catalysed by isolated rat liver ribosomes and EF 1 and EF 2. This is consistent with the results of Olsnes \& Pihl (1972a), who obtained inhibition both of endogenous protein synthesis and of the translation of added messenger poly(U) in a system consisting of a lysate from rabbit reticulocytes. The data of Olsnes \& Pihl (1972a) indicated that the toxin interfered with some component of the cell-free system necessary for the elongation of already initiated polypeptide chains.

Polypeptide-chain elongation, i.e. the translation of the internal codons of mRNA concomitant to the stepwise addition of amino acids from aminoacyltRNA molecules to the growing polypeptide chain, is a repetitive phenomenon which occurs through a cyclic series of reactions (Moldave, 1972). Each cycle can be conveniently divided into three steps: (i) the binding of the appropriate aminoacyl-tRNA at the A site of the ribosome, catalysed by EF 1; (ii) peptide-bond formation at the A site between the 
newly bound aminoacyl-tRNA and the peptidyltRNA present on the $P$ site, catalysed by ribosomal peptidyltransferase; (iii) translocation of the elongated peptidyl-tRNA from the A site back to the $\mathbf{P}$ site, catalysed by EF 2 .

When these three steps were analysed separately, ricin did not affect the binding of aminoacyl-tRNA to ribosomes (Table 3), nor did it inhibit peptidebond formation as assayed by the peptidyl-puromycin reaction (Table 4). The extent of the latter reaction depends on the number of ribosomes carrying peptidyl-tRNA on the puromycin-reactive $P$ site. When ribosomes are preincubated with EF 2 and GTP, translocation of peptidyl-tRNA from the $A$ to the $P$ site occurs, hence increasing the extent of the peptidylpuromycin reaction. Table 4 shows that the presence of ricin during the preincubation with EF 2 and GTP did not affect this single translocation.

On the other hand, when EF 2-catalysed translocation is repetitively involved in the elongation of polypeptide chains, it is severely inhibited by ricin. This is due to damage to ribosomes and not to EF 2, since (i) the extent of inhibition can be decreased by increasing the amount of ribosomes (Table 1) and (ii) inhibition does occur in the absence of ricin with ribosomes pretreated with the toxin (Table 2).

Under the action of ricin ribosomes seem to become unable to interact with EF 2 as indicated by the inhibition of the ribosome-linked GTPase activity of EF 2 measured uncoupled from translocation (Table 5).

Olsnes \& Pihl (1972a) suggested that the inhibitory effect of ricin on elongation is similar to that of diphtheria toxin, although the two toxins act by different mechanisms. Our results indicate that ricin, like diphtheria toxin, inhibits elongation by interfering with the functional interaction of EF 2 with ribosomes. However, diphtheria toxin in the presence of $\mathrm{NAD}^{+}$inactivates EF 2 (Collier, 1967; Honjo et al., 1968), whereas ricin modifies ribosomes and makes them unreactive with added EF 2.

The results of the experiments with a low concentration of ribosomes (Table 1) show that an almost complete inhibition of phenylalanine incorporation is obtained at a molar ratio of ricin to ribosomes of $1: 10$. This ratio appears too low to explain the inhibition on the basis of an irreversible binding of ricin to ribosomes and suggests that ricin may act in a catalytic manner, bringing about an irreversible modification of ribosomes. Olsnes \& Pihl (1972a) suggested that the toxin may act as an enzyme, and showed that inhibition of protein synthesis occurred at a concentration of ricin much lower than that of ribosomes (Olsnes \& Pihl, 1972b). It is noteworthy that whatever the mechanism of ricin action may be, it does not require any added cofactor.

We thank Dr. A. T. Di Marco for the determination of $\mathrm{LD}_{50}, \mathrm{Mr}$. E. Lorenzoni for preparation of ricin and $\mathrm{Mr}$. A. Mattioli for skilful technical assistance. The work was aided by grants from Consiglio Nazionale delle Ricerche, Rome.

\section{References}

Alberghina, F. A. M., Sturani, E. \& Schiaffonati, L. (1971) Arch. Mikrobiol. 80, 166-175

Baliga, B. S. \& Munro, H. N.(1972) Biochim. Biophys. Acta 277, 368-383

Collier, R. J. (1967) J. Mol. Biol. 25, 83-98

Felicetti, L. \& Lipmann, F. (1968) Arch. Biochem. Biophys. 125, 548-557

Honjo, T., Nishizuka, Y., Hayaishi, O. \& Kato, I. (1968) J. Biol. Chem. 243, 3553-3555

Ibuki, F. \& Moldave, K. (1968) J. Biol. Chem. 243, 791798

Lin, J. Y., Tserng, K. Y., Chen, C. C., Lin, L. T. \& Tung, T. A. (1970) Nature (London) 227, 292-293

Lin, J. Y., Liu, K., Chen, C. C. \& Tung, T. C. (1971) Cancer Res. 31, 921-924

Lowry, O. H., Rosebrough, N. J., Farr, A. L. \& Randall, R. J. (1951) J. Biol. Chem. 193, 265-275

Moldave, K. (1972) Frontiers Biol. 27, 465-486

Moldave, K., Galasinski, W. \& Rao, P. (1971) Methods Enzymol. 20, 337-348

Moulé, Y. (1951) Bull. Soc. Chim. Biol. 33, 1461-1466

Olsnes, S. \& Pihl, A. (1972a) FEBS Lett. 20, 327-329

Olsnes, S. \& Pihl, A. (1972b) FEBS Lett. 28, 48-50

Pope, C. G. \& Stevens, M. F. (1958) Brit. J. Exp. Pathol. 39, 139-149

Raeburn, S., Collins, J. F., Moon, H. M. \& Maxwell, E. S. (1971) J. Biol. Chem. 246, 1041-1048

Schneider, J. A. \& Maxwell, E. S. (1973) Biochemistry 12, 475-481

Skogerson, L. \& Moldave, K. (1968) Arch. Biochem. Biophys. 125, 497-505

Sperti, S., Montanaro, L. \& Mattioli, A. (1971) Chem.Biol. Interactions 3, 141-148

Staehelin, T. \& Falvey, A. K. (1971) Methods Enzymol. 20, 433-446

Waller, G. R., Ebner, K. E., Scroggs, R. A., Das Gupta, B. R. \& Corcoran, J. B. (1966) Proc. Soc. Exp. Biol. Med. 121, 685-691 